The Systematics Association Special Volume No. 6

\title{
The Changing Flora and Fauna of Britain
}

edited by D. L. Hawksworth

Commonwealth Mycological Institute, Kew, Surrey, England

May 1974, xiv + 462pp., $£ 9.20 / \$ 23.75 \quad 0.12 .333450 .0$

The present volume represents the proceedings of a symposium of the Systematics Association held at the University of Leicester, in April 1973, on The Changing Flora and Fauna of Britain. The principal purpose of this symposium was to increase the awareness of specialist taxonomists towards the changes occurring in groups of organisms other than their own, and the factors responsible for these. Consequently the work reviews all the available information to date on the changes in the major groups of plants and animals in the British Isles.

\section{Contents}

K. Mellanby: The changing environment. F. H. Perring: Changes in our native vascular plant flora. F. Rose and E. C. Wallace: Changes in the bryophyte flora of Britain. D. L. Hawksworth, B. J. Coppins and F. Rose: Changes in the British lichen flora. D. A. Reid: Changes in the British macromycete flora. C. Booth: The changing flora of microfungi with emphasis on the plant pathogenic species. W. E. Jones: Changes in the seaweed flora of the British Isles. B. A. Whitton: Changes in the British freshwater algae. T. T. Macan: Freshwater invertebrates. A. Wheeler: Changes in the freshwater fish fauna of Britain. G. B. Corbet: The distribution of mammals in historic time. J. T. R. Sharrock: The changing status of breeding birds in Britain and Ireland. $\mathrm{K}$. Williamson: New bird species admitted to the British and Irish lists since 1800 . I. Prestt, A. S. Cooke and K. F. Corbett: British amphibians and reptiles. A. South: Changes in composition of the terrestrial mollusc fauna. J. Heath: A century of change in the Lepidoptera. E. Duffey: Changes in the British spider fauna. J. A. Marshall: The British Orthoptera since 1800. P. M. Hammond: Changes in the British Coleopterous fauna. K. G. V. Smith: Changes in the British Dipterous fauna. K. Mellanby: Arthropod ectoparasites of man. J. C. Felton: Some comments on the Aculeate fauna. K. Mellanby: Summing up. Vice-counties of Great Britain and Ireland. Species Index. Subject index.

\section{Academic Press}

London New York San Francisco A Subsidiary of Harcourt Brace Jovanovich, Publishers 24-28 Oval Road, London NW1, England 111 Fifth Avenue, New York, NY 10003, USA

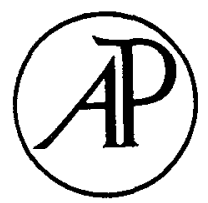




\section{The Biology of Lichens Second Edition}

MASON E. HALE

This is the only unified treatment of lichens available. Emphasis is placed on current areas of research including ultrastructure, physiology, biochemical taxonomy, ecology and chemistry. Recent work with the electron and scanning electron microscope provides much of the new edition's material on fine structure and ultrastructure. It has been extensively revised, particularly in the sections on ecology and air pollution and, except in a few instances where figures are quoted from original papers, units now conform to the SI. Cloth $£ 5.50$ net Paper $£ 2.75$ net

\section{Plant Symbiosis}

GEORGE D. SCOTT

'This excellent work . . . is described as a "booklet" but it contains as much thought and information as found in many larger textbooks. This is achieved by sticking to essentials and avoiding excessive detail combined with a general brevity of statement . . . all plant biologists, and not only those specifically interested in symbiosis, should read this book. Its profound treatment of the subject deserves a wider audience of biologists at all levels. . . . Not since DeBary has symbiosis had a better treatment.'

New Phytologist

Cloth $£$ I.20 net Paper 6op net

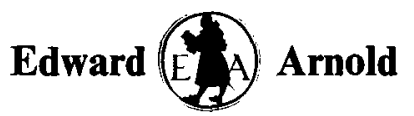

25 Hill Street, London WIX 8LL 


\section{INSTRUCTIONS FOR AUTHORS}

Papers and short notes from contributors anywhere in the world are welcome for consideration for publication in The Lichenologist and may be on any aspect of lichenology.

Manuscripts must be typewritten on foolscap or A4 size paper in double or treble spacing with 1 inch margins all round and should be submitted in duplicate to the Editor. Contributors should retain a copy of their paper for checking the proofs.

Line illustrations must be in black ink on stiff white card, preferably Bristol board.

As a guide to the layout of synonymy, references, etc., recent issues of the journal should be consulted. The spellings of locality names in Britain and abroad must follow those of the most recent editions of maps published by the Ordnance Survey and The Times Atlas of the World, respectively. Titles of periodicals should be abbreviated as in the fourth edition of the World List of Scientific Periodicals and its supplements. In lists of references the publisher and place of publication of books should be given; editions other than the first should be indicated.

Twenty-five reprints of original articles are supplied free. More may be purchased, as may reprints of other contributions such as book reviews. Reprints must be ordered when the author returns the proofs of his article.

Books dealing with any aspect of lichenology will be reviewed. Publishers wishing to have works reviewed in The Lichenologist should send them to the Assistant Editor in the first instance.

This journal is covered by Current Contents and Biological Abstracts.

\section{NOTICE}

While the Editor and Assistant Editor endeavour to check the accuracy of statements in contributions in as far as they are able, it should be emphasized that views expressed in papers in The Lichenologist are those of their authors and do not necessarily represent those of the British Lichen Society, Academic Press Inc. (London) Ltd, the Editor or the Assistant Editor.

\section{REFEREES}

The function of referees, whose names appear inside the front cover, is to assist members of the British Lichen Society in the identification of lichens. Specimens submitted should be adequate in size and well documented, including details of country, county or vice-county, borough or parish, precise locality and grid reference, altitude, date, habitat and ecology, notes, name of collector and collecting number. Identification should be attempted before sending material to a referee and details of spores and chemical reactions included where appropriate. Members wishing to send large numbers of specimens to a referee should first of all check that he is willing to name their collections for them. Return postage should always be included.

\section{MEMBERSHIP}

Membership of the British Lichen Society is open to all persons anywhere in the world interested in any aspect of lichenology. Subscriptions, due on joining and afterwards on 1 January each year, are: ordinary members, £5; junior associate members, $£ 1$; family members $f 0.25$. Details of membership, activities of the Society and application forms may be obtained from the Secretary, Mr J. R. Laundon, Department of Botany, British Museum (Natural History), Cromwell Road, London SW7 5BD, England. Members receive the Bulletin of the British Lichen Society and issues of The Lichenologist published in the year they join, and afterwards while they remain members of the Society, free of charge. Junior associate members do not receive The Lichenologist. 


\title{
THE LICHENOLOGIST
}

Vol. 6 Part 2

KROG, H.-Taxonomic studies in the Hypogymmia intestiniformis complex

KrIstinsson, H.-Two new Cladonia and one new Cetraria species from Iceland

GarTY, J., GaL, M. and GaLUN, M.-The relationship between physicochemical soil properties and substrate choice of 'multisubstrate' lichen species

FARRAR, J. F.-A method for investigating lichen growth rates and succession

Moore, C. C.-A modification of the 'Index of Atmospheric Purity' method for substrate differences

SEAWARD, M. R. D.-Some observations on heavy metal toxicity and tolerance in lichens

GILBERT, O. L.-Reindeer grazing in Britain

\section{Field AND STUdy Note}

WEBER, W. A.-Two lichen-Arthropod associations in Australia and New Guinea

Distribution MAPS OF LichenS IN BRITAIN 169

BOoK REVIEWS

\author{
(C) British Lichen Society 1974 \\ c/o Department of Botany, British Museum (Natural History), \\ Cromwell Road, London SW7 5BD
}

Published twice a year for the British Lichen Society by

Academic Press Inc. (London) Ltd at 24-28 Oval Road, London NW1 7Dx, England

Free to members of the British Lichen Society

1974, Volume 6, 2 issues (April-October): Inland $£ 6.00$ including postage; Abroad £6.90 including postage. Subscription orders should be sent to Academic Press Inc. (London) Ltd, 24-28 Oval Road, London NW1 7Dx, England, except those from Canada, Central and South America and the U.S.A., which should be sent to Academic Press Inc., 111 Fifth Avenue, N.Y. 10003, U.S.A. Subscriptions from these countries: $\$ 16.00$ including postage. 